\title{
PENDAMPINGAN DAN PENERAPAN STRATEGI DIGITAL MARKETING BAGI UMKM TERDAMPAK PANDEMI COVID-19
}

\author{
Zanuar Rifai, Dwi Meiliana \\ Universitas Amikom Purwokerto \\ zanuar.rifai@amikompurwokerto.ac.id
}

\begin{abstract}
The Covid-19 pandemic has spread almost throughout the world, including Indonesia, this pandemic has had a tremendous impact on all sectors, including the MSME sector. The MSME sector has a large contribution to gross domestic product (GDP). The Covid-19 pandemic has had a very negative impact on MSMEs, at this time MSMEs have difficulty in marketing their products due to social distance policies. At this time, MSME marketing is only through conventional means, MSME players have also not implemented digital marketing because of limited knowledge of MSME players. The purpose of this activity is to accompany and implement a Digital Marketing Strategy so that MSME players can apply a Digital Marketing strategy in selling their products. The result of this activity is increased knowledge about digital marketing strategies and can also create marketing content.
\end{abstract}

Keywords: Digital marketing; Content Marketing; Covid-19

\begin{abstract}
Abstrak
Pandemi covid-19 menyebar hampir seluruh dunia tidak terkecuali indonesia, pandemi tersebut memberikan dampak yang luar biasa bagi semua sektor tidak terkecuali sektor UMKM. Sektor UMKM mempunyai kontribusi yang besar terhadap produk domestik bruto (PDB). Pandemi covid19 telah memberikan dampak yang sangat negatif bagi UMKM, pada saat ini UMKM kesulitan dalam memasarkan produk-produknya karena adanya kebjikana social distance. Pada saat ini pemasaran UMKM hanya melalui cara konvensional, pada pelaku UMKM juga belum menerapakan pemasaran secara digital karena keterbatasan pengetahuan pada pelaku UMKM. Tujuan dari kegiatan ini adalah mendampingi dan menerapkan Digital Marketing Strategi sehingga para pelaku UMKM dapat menerapkan strategi Digital Marketing dalam menjual produknya. Hasil kegiatan ini adalah bertambahnya pengetahuan tentang strategi Digital Marketing dan juga dapat membuat konten marketing.
\end{abstract}

Kata Kunci: Digital marketing; Content Marketing; Covid-19

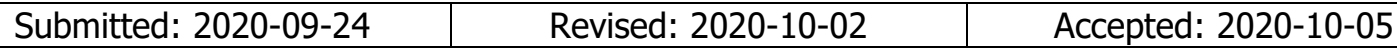

\section{Pendahuluan}

Pandemi Covid19 menyebar hampir di 200 negara tidak terkecuali Indonesia. Dampak dari pandemi tersebut menyebabkan krisis diberbagai sektor, baik sektor kesehatan, pendidikan dan sektor ekonomi. Adanya krisis ekonomi akibat adanya pademi covid19 mempunyai dampak yang luarbiasa bagi sektor UMKM. UMKM di Indonesia merupakan penyumbang terbesar PDB menjadi andalan dalam penyerapan pengangguran, subtitusi produksi barang konsumsi, mensubtitusi produksi barang konsumsi atau setengah jadi(Awali \& Rohmah, 2020). Data Kementerian Koperasi dan Usaha Kecil dan Menengah Indonesia tahun 2018 menunjukkan bahwa jumlah unit usaha 
UMKM 99,9\% dari total unit usaha atau 62,9 juta unit. Daya serap UMKM 97\% dari total penyerapan tenaga kerja, $89 \%$ di antaranya ada pada sektor mikro, dan dapat menyumbang $60 \%$ terhadap produk domestik bruto. Peran UMKM menjadi sangat penting dalam perekonomian Indonesia. Berdasarkan Survey yang dilakukan oleh Asosiasi Business Development Services Indonesia (ABDSI) dampak Covid-19 terhadap UMKM begitu terasa. Hampir seluruh UMKM mengalami penurunan penjualan. Sebesar $36.7 \%$ pelaku UMKM tidak memperoleh penjualan, sedangkan $26 \%$ nya mengalami penurunan penjualan lebih dari $60 \%$. Kebanyakan UMKM mengalami masalah pada ketersediaan bahan baku dan pembayaran kredit((ABDSI), 2020)

Pandemi COVID-19 memberikan implikasi ekonomi, sosial, dan politik tidak saja negara-negara besar akan tetapi hamper seluruh negara di dunia. Rasanya tidak ada satu negarapun yang tidak terdampak pandemic COVID-19 saat ini. Indonesia adalah salah satu negara yang terdampak terutama pada sisi ekonomi. Indonesia yang didominasi oleh Usaha Mikro, kecil, dan Menengah (UMKM) perlu memberikan perhatian khusus terhadap sektor ini karena kontribusi UMKM terhadap pereknomian nasional yang cukup besar. Tulisan pendek ini mencoba untuk menganalisa dampak pandemi COVID-19 terhadap eksistensi UMKM di Indonesia dan bagaimana solusi darurat dalam membantu UMKM bertahan dalam situasi pandemi COVID-19(Pakpahan, 2020). Jumlah kasus Covid-19 yang semakin meningkat melemahkan perekonomian nasional maupun internasional. Berbagai sektor bisnis mengalami perlambatan akibat virus Covid-19. Mulai dari sektor pariwisata, penerbangan, perhotelan, farmasi, alat berat, otomotif, perkebunan hingga pertambangan batubara. Dalam situasi krisis seperti ini, UMKM dapat menjadi andalan dalam penyerapan tenaga kerja, penggantian produksi barang konsumsi atau setengah jadi. Tulisan ini mengkaji dampak wabah Covid-19 terhadap perlambatan ekonomi sektor UMKM serta melihat upaya pemerintah dalam memperkuat UMKM. Hal yang terdampak oleh Covid-19 dalam UMKM adalah penyerapan produk, ketersediaan bahan baku, dan proses distribusi. Dalam mengatasi hal ini pemerintah memberikan stimulus yang ditargetkan pada industri pariwisata, penambahan cuti bersama juga dilakukan guna mendorong pariwisata, dan restrukturisasi kredit UMKM, selain itu call center juga disediakan untuk mendengar laporan dan keluhan pelaku UMKM. DPR RI perlu mendorong pemerintah untuk membangun UMKM di titik-titik bebas Covid-19 dan menjaga daya beli masyarakat untuk menjaga keberlangsungan UMKM(Bahtiar \& Saragih, 2020). Pandemi Covid-19 memberikan dampak yang luar biasa terhadap berbagai sektor, khususnya sektor perekonomian, dimana keberadaan UMKM yang peranannya memberikan sumbangsih yang cukup besar terhadap laju perekonomian tidak lepas terdampak dari wabah Covid-19, dalam penelitian ini melihat sejauh mana urgensi pemanfaatan E-Marketing untuk keberlangsungan UMKM di Kota Pekalongan ditengah pandemi Covid-19. Penelitian ini menggunakan metode kualitatif dengan pendekatan fenomenologi.

\section{Metode}

Untuk mencapai keberhasilan dalam kegiatan ini diperlukan kerjasama dari beberapa pihak, adapun pihak-pihak yang telibat pada kegiatan ini adalah Pihak dari 
pengusul perguruan tinggi, pihak dari mitra UMKM. Tahapan pada kegiatan ini dapat dilihat pada gambar dibawah ini:

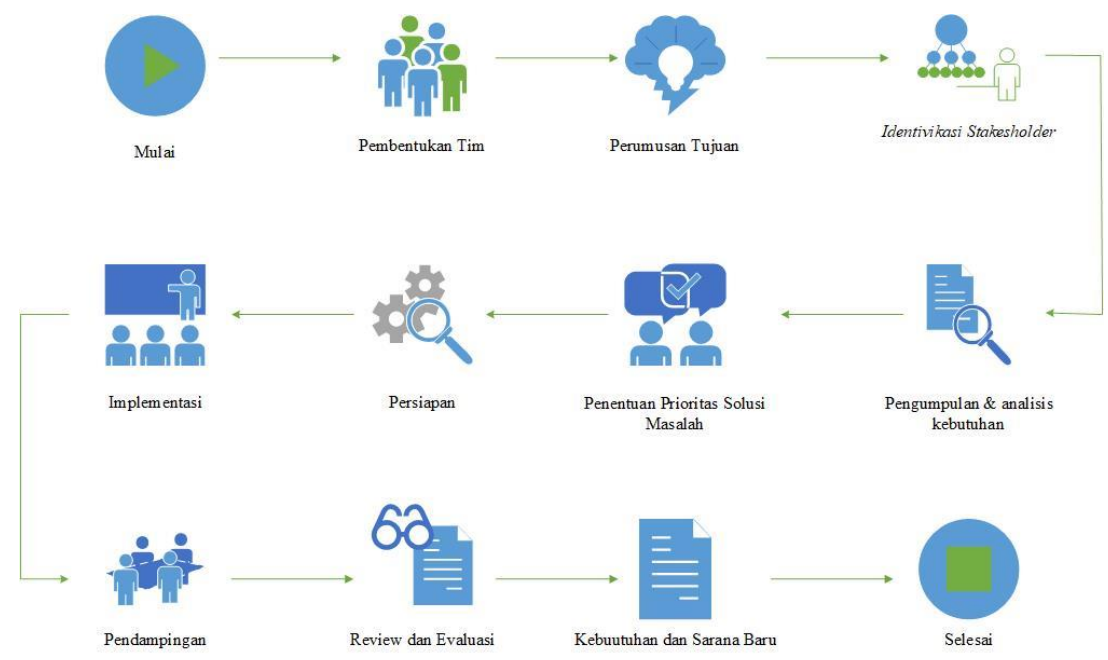

Gambar 1. Tahapan Pelaksanaan

Metode yang digunakana pada kegiatan ini adalah metode peltihan dan juga pendampingan dalam menerapkan strategei digital marketing. Pada tahap pelatihan mitra akan dilatih tentang strategi digital marketing kemudian akan diberi dampingan sampai mitra benar-benar bias menerapkan startgei digital marketing.

\section{Hasil dan Pembahasan}

Kegiatan pengabdian ini dilaksanakan selama 3 hari, yaitu tanggal 14-16 September 2020. Pada hari pertama kegiatan dibagi menjadi 2 sesi, pada sesi pertama mitra diberikan pengetahuan tentang digital marketing, mulai dari konsep digital marketing dan mengetahui produknya dan memahami value produk masing-masing. Dampak dari kegiatan ini adalah aanya peningkatan pengetahuan dan ketrampilan dalam menerapkan stratgei digital marketing. Mitra dapat memahami tahap-tahapan dan proses dalam dunia digital marketing.

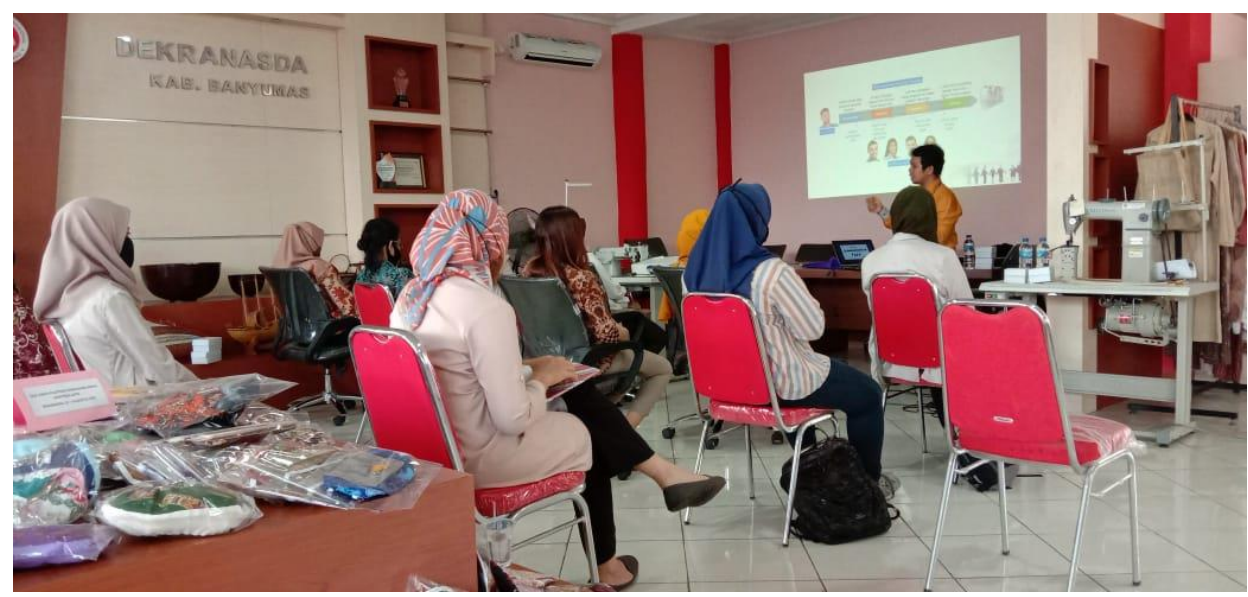

Gambar 2. Pemahaman Digital Marketing 
Selanjutnya pada sesi kedua mitra diberikan pengetahuan tentang konten gambar, tujuan dari kegiatan ini adalah agar para mitra dapat membuat konten marketing dalam bentuk gambar yang sederhana dan mudah dalam pembuatannya, berikut adalah hasil dari kegiatan tersebut:
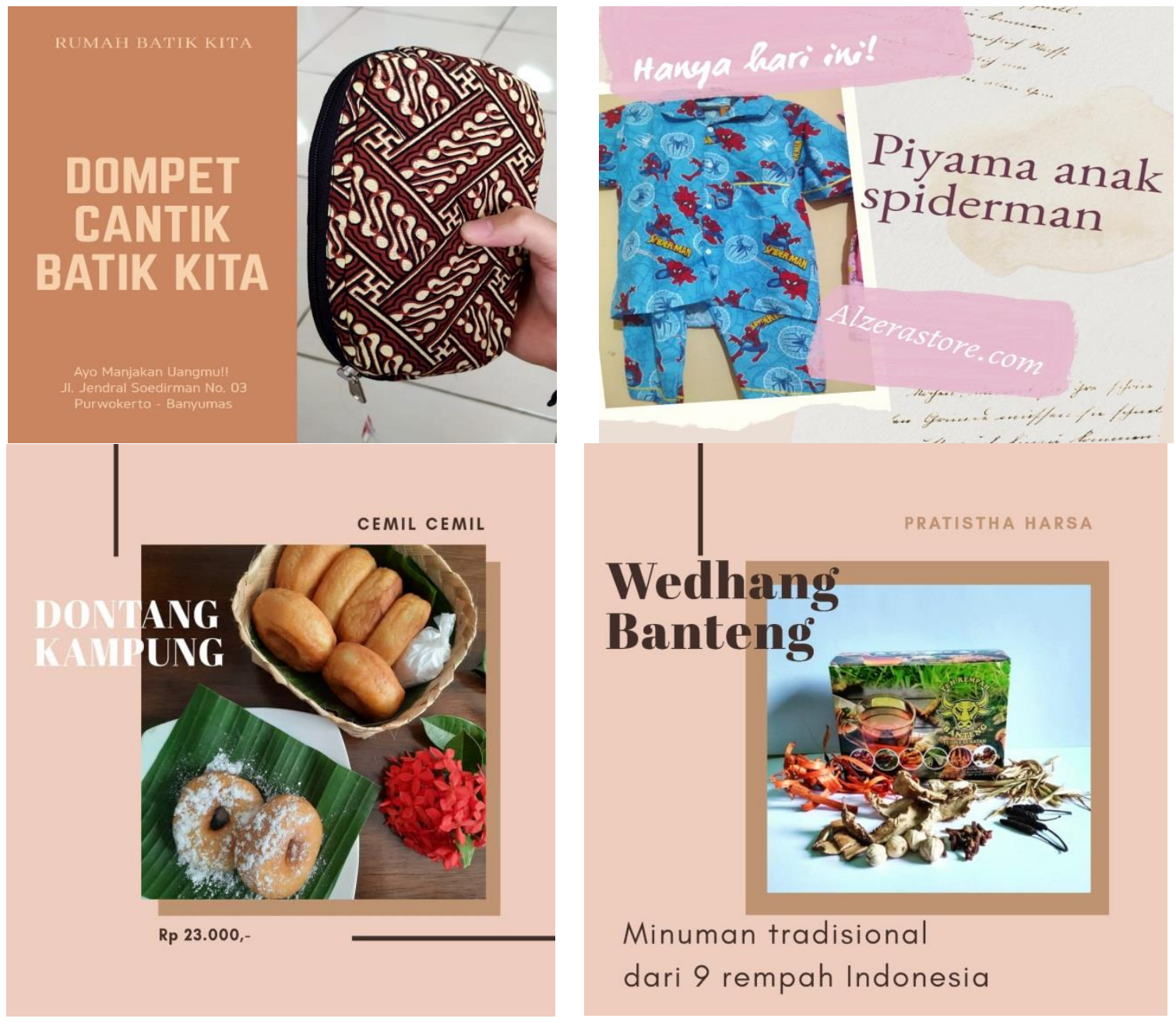

Gambar 3. hasil editing gambar dari mitra

Pada hari kedua kegiatan pengabdian juga dibagi menjadi 2 sesi, sesi pertama mitra diberikan pengetahuan tentang iklan berbayar facebook ads, mitra diajarkan bagaimana membuat sebuah fanspage, membuat postingan pertama menggunakan konten yang dibuat pada hari sebelumnya dan menentukan target pasar, demography, peminatan dan copywriting. Hasinya masing-masing dapat membuat sebuah fanspage untuk masing-masing produk/jasanya. Berikut adalah foto kegiatan pada hari kedua sesi pertama: 

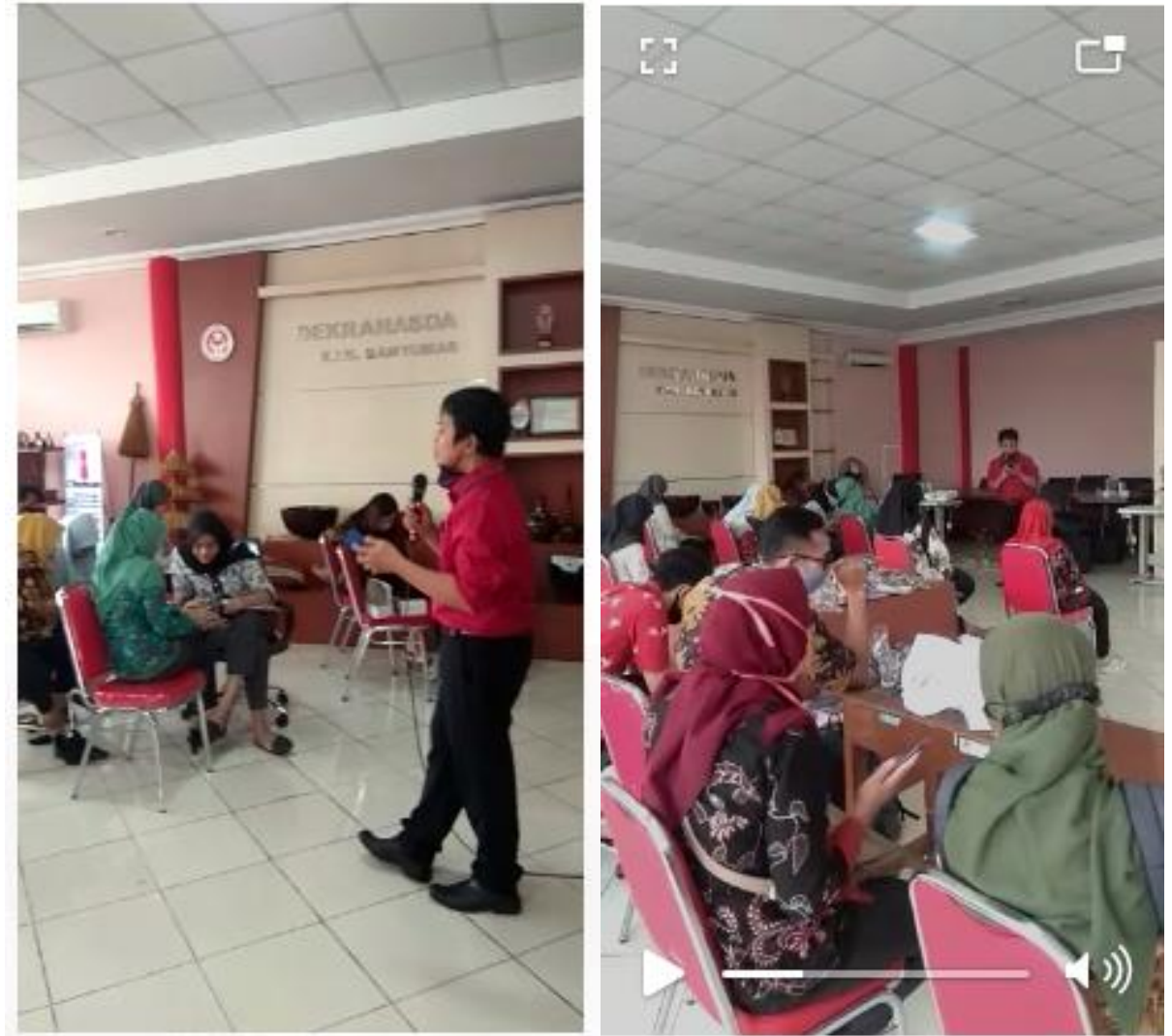

Gambar 4. Praktek Facebook ads

Selanjutnya pada sesi kedua mitra diberikan pengetahuan tentang konten video tujuan dari kegiatan ini adalah agar para mitra dapat membuat konten marketing dalam bentuk video yang sederhana dan mudah dalam pembuatannya, berikut adalah hasil dari kegiatan tersebut:

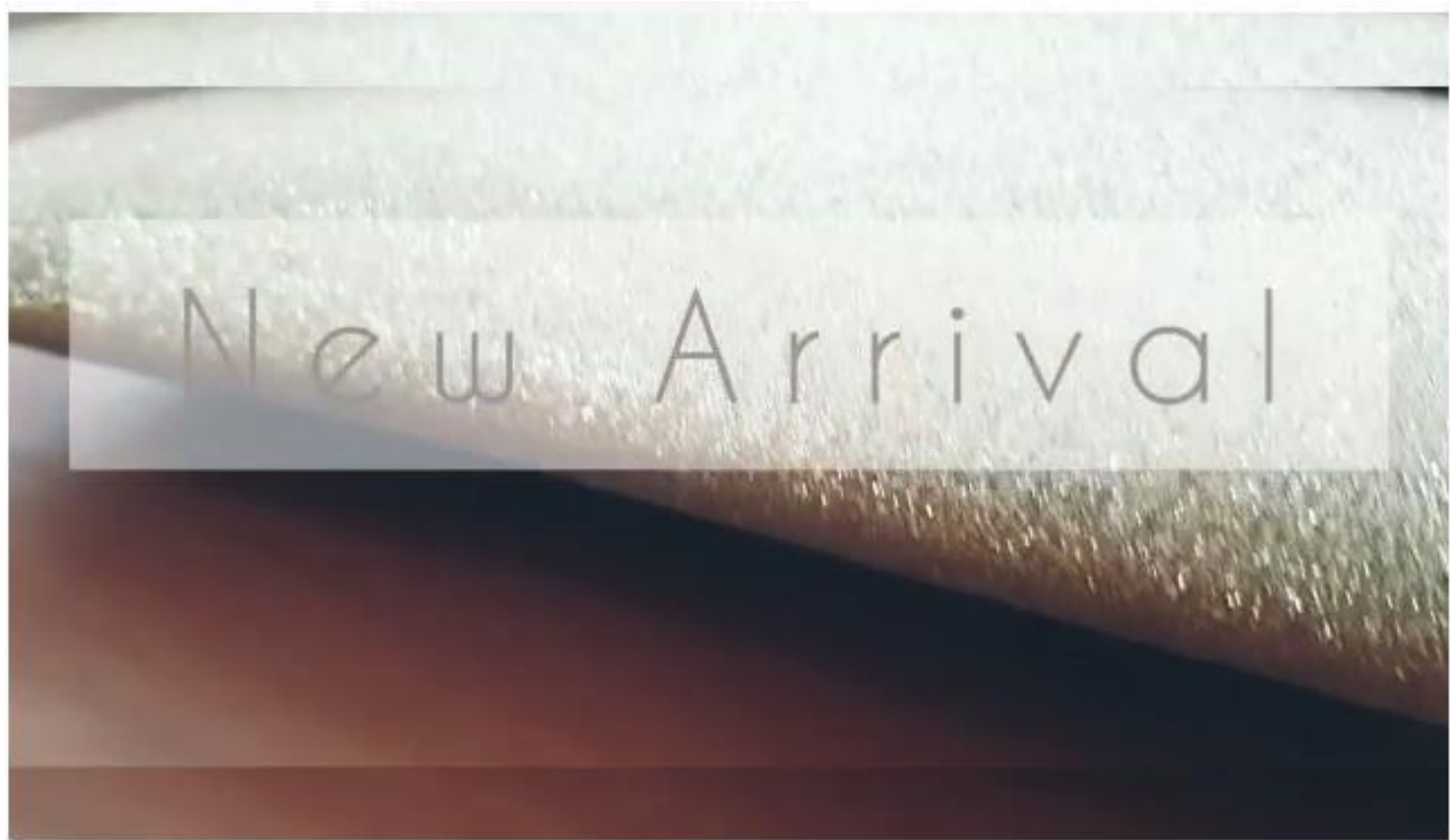

Gambar 5. Hasil Editing Video Dari Mitra 


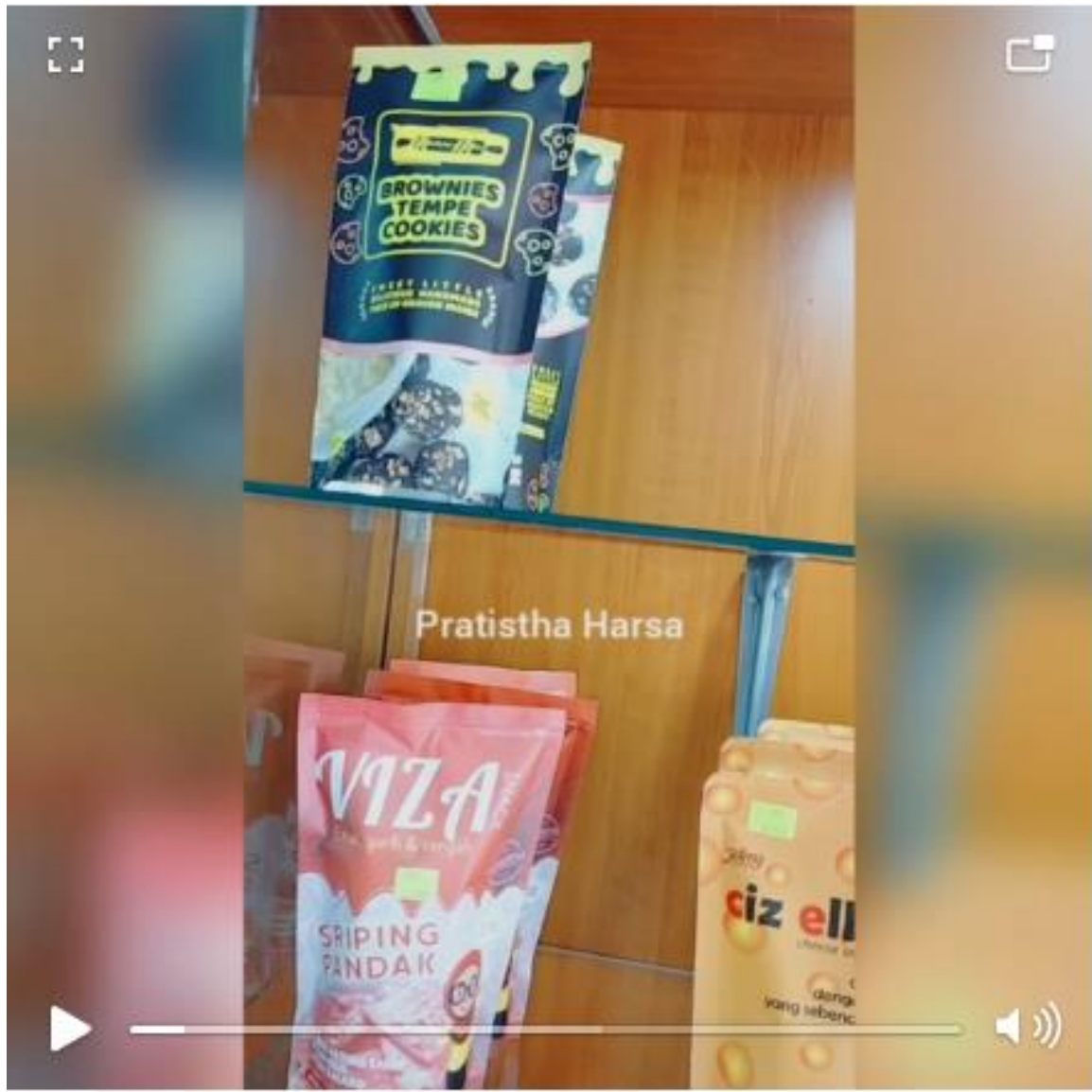

Gambar 6. Hasil Editing Video Dari Mitra

\section{Kesimpulan}

Kesimpulan dari kegiatan pengabdian kepada masyarakat adalah bertambahnya pengetahuan mitra tentang Digital Marketing, mitra menjadi paham ketika akan emnyusun strategi digital marketing. Mitra juga langusung mempraktekan ilmu tentang digital marketing mulai dari menyusun strateginya, membuat konten gambar, membuat konten video dan mengiklankan konten tersebut melalui facebook dan instagram.

\section{Daftar Pustaka}

(ABDSI), A. B. D. S. I. (2020). Survey yang Asosiasi Business Development Services Indonesia (ABDSI) dampak Covid-19 terhadap UMKM. http://www.abdsi.id/bappenas-sarankan-umkm-terdampak-covid-19-perlupendampingan/

Awali, H., \& Rohmah, F. (2020). Urgensi Pemanfaatan E-Marketing Pada Keberlangsungan UMKM di Kota Pekalongan Di Tengah Dampak COVID-19. Balanca: Jurnal Ekonomi Dan Bisnis Islam, 2, 1-14.

Bahtiar, R. A., \& Saragih, J. P. (2020). Dampak Covid-19 terhadap perlambatan ekonomi sektor umkm. Jurnal Bidang Ekonomi Dan Kebijakan Publik, 76), 19-24.

Pakpahan, A. K. (2020). Covid-19 Dan Implikasi Bagi Usaha Mikro, Kecil, Dan Menengah. JIHI: Jurnal IImu Hubungan Internasional, 20(April), 2-6. https://doi.org/https://doi.org/10.26593/jihi.v0i0.3870.59-64 